\title{
Bone Marrow Ablation with Stem Cell Support
}

National Cancer Institute

\section{Source}

National Cancer Institute. Bone Marrow Ablation with Stem Cell Support. NCI Thesaurus.

Code C15587.

Bone marrow ablation followed by replacement of stem cells in the circulating blood to help the bone marrow recover and continue producing healthy blood cells. 